\title{
Deploying a "Good Jobs" Strategy in Service Sectors for Enhancing Competitive Advantage
}

\author{
Pankaj M. Madhani, ICFAI Business School, India
}

(iD https://orcid.org/0000-0002-8810-3201

\begin{abstract}
Many service companies believe that there is a trade-off between investing in employees and offering the lowest prices. They offer few benefits, no career paths, and, hence, are considered as bad jobs. Conventional wisdom holds that bad jobs are the unavoidable price of low-cost service. However, this research emphasizes that investing in people and processes actually can boost customer experience and decrease costs. The good jobs strategy is a model for investing and empowering front-line employees in service industries and revamping operations to support those employees. The good jobs strategy is an approach to improving productivity and customer satisfaction in service industries. This research works in this direction and develops various frameworks for smooth deployment of the good jobs strategy. The research also formulates financial measurement and evaluation models for calculating benefits of the good jobs strategy and provides diverse illustrations of its successful deployment.
\end{abstract}

\section{KEYWORDS}

Bad Jobs, Cross-Training, Employee Turnover, Good Jobs, Human Resources, Operations, Retail, Service Industry, Simplification, Slack, Standardization

\section{INTRODUCTION}

There has been a lot of discussion over the last few years about the growth of the services sector - in terms of nations' GDP and people's occupations - compared to the manufacturing sector, which had dominated the business scenario earlier. Service-related jobs and activities have grown to encompass a much larger share of the global economy and job market. The service sector grew significantly in the late twentieth century, to the extent that 80 percent of jobs in the USA were offered by service companies (Heineke and Davis, 2007). More than 80 percent of all jobs in the USA are in the service sector (Bureau of Labor Statistics, 2015) which is 11 percent higher than service-related employment in 1990. Similarly, significant proportions of the gross domestic product generated in emerging economies can be attributed to services (Loungani and Mishra, 2014). As of June 2020, 117.36 million people in USA ( $85 \%$ of all nonfarm payroll employees) worked in private service-providing industries. Among the major service-industry sectors, the biggest was trade, transportation and utilities (Bureau of Labor Statistics, 2020).

Service jobs are also undergoing significant changes as a result of technological innovations; check-in kiosks; robo-advisors, and self-checkouts - all of which suggesta trend toward the automation of many standard customer-facing tasks (e.g. retail, banking, insurance and financial services) (Singh et al., 2017). These trends suggest a need to essentially redesign frontline employee roles to integrate

\section{DOI: 10.4018/IJBSA.20210101.oa3}

This article, published as an Open Access article on December 18, 2020 in the gold Open Access journal, International Journal of Business Strategy and Automation (converted to gold Open Access January 1, 2021), is distributed under the terms of the Creative Commons Attribution License (http://creativecommons.org/licenses/by/4.0/) which permits unrestricted use, distribution, and production in any medium, provided the author of the original work and original publication source are properly credited. 
technology with employee behaviours (Rafaeli et al., 2017); select, reward, train, and retain employees to build long-term relationships with customers (Zablah et al., 2017); and utilize employees as agents of innovation as opposed to simply implementing standardize service scripts (Bowen, 2016).

Human resources (HR) and how they are managed, are vital sources of competitive advantage because of diminishing contributions derived from other resources. Earlier resources like product technologies, protected markets and access to financial resources were traditionally considered as sources of competitive advantage (Pfeffer, 1995). Hence, a growing number of service companies that have long offered frontline workers low pay, few benefits, unpredictable schedules, and dead-end careers are abandoning or at least questioning their model. High performing companies in service industry are able to create a culture that emphasizes the value of people, flexibility in scheduling, innovative staffing practices, training and development, and performance management (Hinkin and Tracey, 2010).

Frontline service employees have been described as "typically underpaid, undertrained, overworked and highly stressed" (Hartline and Ferrell, 1996). According to the job demands -resources model (Demerouti et al., 2001) characteristics of a job can be classified as either job demands or job resources. Job demands are aspects of the job that require sustained effort, whereas job resources are job characteristics that support the employee in coping successfully with job demands, attaining work goals, and achieving personal growth (Schaufeli and Bakker, 2004). For service employees, excess job demands and a lack of job resources exert an energy-draining effect on employees through a stress process. As in-service role demands often exceed resources, service employees are highly vulnerable to burnout, a syndrome consisting of emotional exhaustion, depersonalization, and a reduction of one's sense of personal accomplishment (Maslach and Leiter, 2008).

Many employees in service industry, experience long operating hours, relatively high turnover, and relatively low pay as many managers believe that there is a trade-off between investing in employees and offering the lowest prices. That, too, is false as investing in people and processes actually can boost customer experience and decrease costs. Companies can compete successfully on the basis of low prices and simultaneously keep their customers and employees happy. This approach known as Good Jobs strategy is a model for investing in frontline employees in service industries and revamping operations to support those employees. Good Jobs strategy can be not only profitable but even profit maximizing in mass market services (Ton and Harrow, 2010; Ager and Roberto, 2013; Ton, 2014).

The major objectives of this paper are firstly, to introduce concept of the Good Jobs strategy as a value creation strategy which combines the strengths of both human resource management (HRM) and operations and emphasize their complementary relationship; secondly, to demonstrate how Good Jobs strategy meets the challenges of employees, customers and companies in today's fast changing and highly competitive services marketplace; and thirdly, to suggest various research frameworks for successful deployment of Good Jobs strategy by analyzing matching organizational resources in terms of people (HRM practices) and processes (operational excellence). Finally, this study focuses on the how to measure and quantify enhanced business performance on deployment of Good Jobs strategy. Accordingly, research develops various models: Financial Measurement Model (FMM) to identify and segregate various performance drivers of Good Jobs strategy and Financial Evaluation Model (FEM) to evaluate impact of these performance drivers on top-line and bottom-line of a company.

This paper is organised in different sections. In addition to this introductory section, the paper contains the following sections. Section 2 explains the research methodology and develops various models to identify, segregate and evaluate various benefits of Good Jobs strategy. Section 3 outlines literature review and Section 4 compares Good Jobs and Bad Jobs. Section 5 provides details of Good Jobs strategy in terms of synergy of HR and operations and Section 6 presents major building blocks of Good Jobs strategy. Section 7 describes various illustrations of successful deployment of Good Jobs strategy in service companies. Section 8 presents the managerial implications, limitations and scope for future work. Finally, section 9 concludes with the major research findings. 


\section{RESEARCH METHODOLOGY}

Companies in service industry typically don't prioritize Good Jobs strategy because, although it sounds good, they're not convinced it's affordable. The huge costs of decent wages or benefits are immediate and easy to quantify, while the greatest future benefits of Good Jobs strategy are harder to measure. The financial benefits of downsizing and reducing employees are direct, immediate, and easy to quantify, whereas the less-desirable effects are indirect, long-term, and difficult to measure. Hence, the research works in this direction and uses two stages approach. In the first stage, research develops Financial Measurement Model (FMM) to identify and segregate various performance drivers (i.e. increased revenue, cost reductions and employee productivity) of Good Jobs strategy. In the second stage, research formulates Financial Evaluation Model (FEM) to evaluate impact of Good Jobs strategy performance drivers on top-line and bottom-line of the service company.

\subsection{Financial Measurement Model (FMM)}

Good Jobs strategy enhances a reputation of a company as a trustworthy employer (Ton, 2014) and triggers a signal to stakeholders other than employees that a particular firm is trustworthy in general (Fombrun and Shanley, 1990). Employer trustworthiness reduces the agency costs of monitoring and asymmetric information, and enhances the exchange of information across the firm. There is a positive correlation between knowledge sharing and job satisfaction, indicating that knowledge sharing contributes to improved team performance by increasing job satisfaction (Kasemsap, 2014). These benefits are expected to improve the efficiency of operations across the firm by generating less waste, more cooperation, and less work-related distractions (Butler et al., 2016). Such reputation as a trustworthy employer would positively influence all stakeholders and attract new employees (Turban and Cable, 2003), suppliers (Roberts and Dowling, 2002), alliance partners (Eisenhardt and Schoonhoven, 1996; Das and Teng, 2001), and customers (Shapiro, 1983) who perceive their own performance benefits from being associated with such company. Thus, it increases efficiency and productivity of the firm due to better synergy among stakeholders.

The Good Jobs strategy makes investment in people and operations by increasing employee wages and benefits, improving work schedules, developing and promoting employees, and making job improvement with standardization of certain tasks. Such investment ensures that employees are motivated, capable and productive and hence, can contribute to higher sales and lower costs. However, in short term these initiatives cost more but are worth even more than that. Most companies still continue with status quo as they cannot quantify both the true costs of this status quo and the potential financial gains of building a better system (Bach et al., 2019). The costs of continuing with the status quo are often hidden as top management does know how much it is losing every day. Organization doesn't realize that such status quo badly impact the organization's competitiveness and long term survival. Hence, there is a need for developing a methodology to emphasize financial benefits of Good Jobs strategy (i.e. increasing the company's investment in its people and enhancing operational capability to improve their work). Hence, this research develops a financial measurement model to quantify three types of performance drivers envisaged on deployment of Good Jobs strategy (Figure 1):

1. Increased Revenue (IR): Good Jobs strategy increases revenue of the organization. Higher revenues results from better operational execution (e.g., fewer stock-outs and abandoned transactions); increased basket size (i.e., customers buying more per store visit) and higher number of transactions (from higher traffic) that comes from a better customer experience.

2. Cost Reductions (CR): Good Jobs strategy decreases overall costs of the organization. Cost reductions is derived from lower employee turnover, better operational execution (e.g., shrink), and reduced costs of overtime and unplanned labor.

3. Employee Productivity (EP): Good Jobs strategy enhances employee productivity. Productivity gain for employees results from better workload management (e.g., cross-training of employees 
and smoothing of the workload) and from less time wasted by poor task allocation, poor logistical systems (such as long delivery windows), and frequent and last-minute changes.

\subsection{Financial Evaluation Model (FEM)}

In view of low profit margin, the focus of companies in service sector remained on minimizing labor costs. However it has led to Bad Jobs, high employee turnover, poor customer satisfaction and ultimately poorly run stores. Good Jobs strategy focus on increasing employees' wages and benefits, improving work schedules, and building systems to develop and promote employees. It also involved standardizing certain tasks while empowering employees to solve customer problems as they arise. Such empowerment and job improvement ensures that employees are productive and can contribute to higher sales and lower costs. Every company would be better served by Good Jobs strategy as the assumed trade-off between low prices and Good Jobs is a fallacy. Table 1, shows Financial Evaluation Model (FEM) to quantify impact of Good Jobs strategy on top-line and bottom-line of a service company and also identifies Good Jobs strategy performance drivers along with related performance improvement.

\subsection{Illustration}

An illustration of a fictional grocery retail store is explained below. It segregates various performance drivers of Good Jobs strategy as explained earlier in Financial Evaluation Model (FEM). It also explains how top management may quantify the upside in top-line and bottom-line triggered by these performance drivers. Increased revenue (IR) is due to increased customer satisfaction and loyalty from better service (e.g., helpful, knowledgeable employees, clean stores with fully stocked shelves, and shorter checkout lines). Cost reduction (CR) results from better employee turnover, effective operational execution. Employee productivity (EP) gain results from better task allocation and workload management. In this illustration, it is envisaged that on the Good Jobs strategy deployment, retailer generates a $1 \%$ positive impact across revenue, costs and overhead expenses. Table 2 , represents a Financial Evaluation Model (FEM) for a retailer (base case) as well as after positive impact of Good Jobs strategy deployment (new case). All figures are in millions of U.S. dollars.

With $1 \%$ improvement in sales revenue (with performance driver - IR) triggered by deployment of Good Jobs strategy by a retailer, new sales become $\$ 101 \mathrm{M}$. As COGS varies directly in proportion with sales, COGS has increased to $\$ 85.85 \mathrm{M}$. After considering, impact of $1 \%$ improvement (with performance driver - CR) in COGS, new COGS is reduced to $\$ 84.99 \mathrm{M}$. On Good Jobs strategy deployment, $1 \%$ improvement in selling expense, G\&A expense and logistics expense (with performance drivers - CR and EP) caused considerable cost reduction. As shown in Table 2, with Good Jobs strategy, even a small improvement in various performance drivers such as IR, CR and $\mathrm{EP}$, across the retail operations can have a profound effect on the bottom line and lift net income of a retailer by approximately $18.3 \%$.

\section{LITERATURE REVIEW}

Literature review is classified and presented according to research focus, to support main theme of the research i.e. Good Jobs strategy in service sectors.

\subsection{Service Jobs}

Service jobs can be classified in two categories: (1) low-skilled, low-complexity and standardized (e.g. in retail or fast food) and (2) complex high skilled with intellectual or relational requirements (e.g. professional services or healthcare). Jobs with low complexity service can be replaced more easily; however, in jobs with high complexity, human capital is less replaceable (Subramony et al., 2017). 


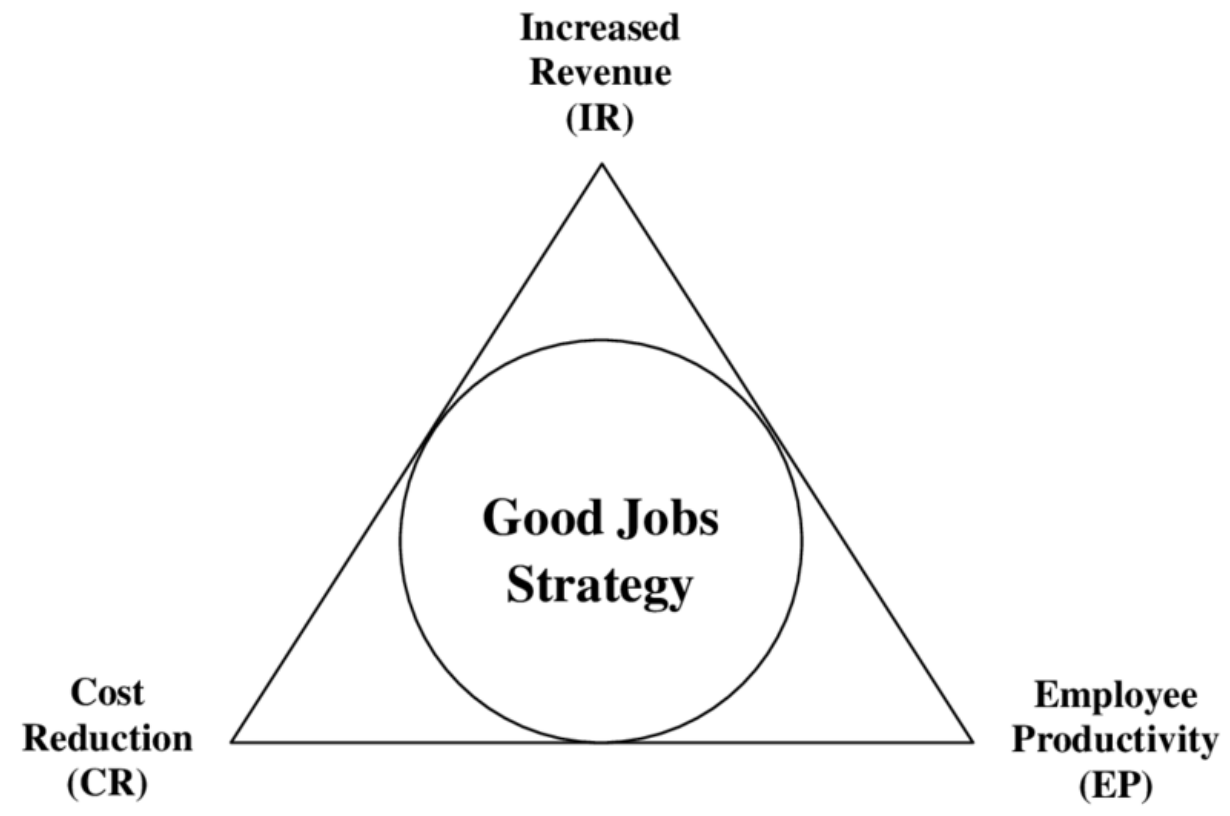

Similarly, service jobs are also segregated as creative intensive or routine-intensive jobs. Creativityintensive jobs involve a high level of independent judgment and decision making (e.g. marketing manager). They are given the space and freedom to create value for their employers. Routine-intensive jobs involve little independent judgment and decision making (e.g. accounting clerks) and they earn significantly lower wages (Martin, 2017).

Many low-wage and low-skills jobs have the characteristics that have attributed to Bad Jobs: low wages with little probability of advancement, limited benefits, lack of control over work activity, and lack of flexibility to respond to non-work demands (Kallenberg, 2011). In service industry, millions of workers are stuck in low-wage occupations and the numbers continue to grow. In 2015, 39\% of all entry-level jobs in US required no more than a high school diploma or GED (General Educational Development). Many of these low-education jobs are part time with irregular hours and few health care or retirement benefits. Many people are stuck in low-wage positions for much of their work life and that these jobs are the primary work activity for many families. According to US Bureau of Labor Statistics (BLS), this percentage will be almost the same in 2026, at 38\%. During the 10-year forecast period (2016-26), these low-education positions are expected to increase by $5.1 \%$ or 3.1 million. The BLS projects that $62 \%$ of entry-level jobs in 2026 will not require any college. These occupations will include various jobs of service industry such as retail salespersons, cashiers, janitors, maids and housekeeping cleaners, stock clerks, personal care aides, groundskeepers, and food servers (US Bureau of Labor Statistics, 2019).

Mass market services - including retail, leisure, healthcare and social services - account for over $30 \%$ of US employment (Bureau of Labor Statistics 2017a). Most companies in these industries minimize labor costs with (a) low wages - median hourly wages are \$9-12 (Bureau of Labor Statistics 2017b), (b) poor benefits (Carre et al., 2010), (c) routinized low-skill tasks (Appelbaum and Schmitt 
Table 1. Financial Evaluation Model (FEM): Impact on Top-line and Bottom-line

\begin{tabular}{|c|c|c|c|c|}
\hline $\begin{array}{l}\text { Sr. } \\
\text { No. }\end{array}$ & $\begin{array}{l}\text { Net Income } \\
\text { Calculation }\end{array}$ & $\begin{array}{l}\text { Impact of Good Jobs } \\
\text { Strategy in Retail }\end{array}$ & $\begin{array}{l}\text { Good Jobs Strategy } \\
\text { Performance Drivers }\end{array}$ & $\begin{array}{c}\text { Performance Improvement } \\
\text { With Good Jobs Strategy } \\
\text { Deployment }\end{array}$ \\
\hline (1) & Sales Revenue & Increase & Increased Revenue (IR) & $\begin{array}{l}\cdot \text { Faster response to customer } \\
\text { needs } \\
\cdot \text { Increased availability of } \\
\text { desired products } \\
\cdot \text { Better operational execution } \\
\text { (e.g., fewer stock outs and } \\
\text { abandoned transactions) } \\
\cdot \text { Increased basket size (i.e., } \\
\text { customers buying more per store } \\
\text { visit) } \\
\cdot \text { Higher number of transactions } \\
\text { (from higher traffic) that } \\
\text { come from a better customer } \\
\text { experience } \\
\cdot \text { Higher customer retention rate }\end{array}$ \\
\hline (2) & $\begin{array}{l}\text { COGS (Cost of } \\
\text { Goods Sold) }\end{array}$ & Decrease & Cost Reductions (CR) & $\begin{array}{l}\cdot \text { Better management of } \\
\text { inventory } \\
\cdot \text { Reduced wastes } \\
\cdot \text { Cost reductions from } \\
\text { improving employee turnover } \\
\cdot \text { Reduction of shrink } \\
\cdot \text { Cost reductions from overtime } \\
\text { and unplanned labor }\end{array}$ \\
\hline (3) & $\begin{array}{l}\text { Gross Profit = } \\
(1)-(2)\end{array}$ & Increase & $\begin{array}{l}\text { Increased Revenue (IR) } \\
\text { Cost Reductions (CR) }\end{array}$ & - Increase in gross profit \\
\hline (4) & Selling Expense & Decrease & $\begin{array}{l}\text { Cost Reductions (CR) } \\
\text { Employee Productivity } \\
(\mathrm{EP})\end{array}$ & $\begin{array}{l}\text { - Lower customer acquisition } \\
\text { cost }\end{array}$ \\
\hline (5) & $\begin{array}{l}\text { G \& A (General } \\
\& \text { Administrative) } \\
\text { Expense }\end{array}$ & Decrease & $\begin{array}{l}\text { Cost Reductions (CR) } \\
\text { Employee Productivity } \\
\text { (EP) }\end{array}$ & $\begin{array}{l}\text { Reduced transaction expenses } \\
\cdot \text { Better resource utilization }\end{array}$ \\
\hline (6) & Logistics Expense & Decrease & $\begin{array}{l}\text { Employee Productivity } \\
\text { (EP) }\end{array}$ & $\begin{array}{l}\text {. Optimized transportation } \\
\text { expenses } \\
\cdot \text { Better transparency and } \\
\text { visibility } \\
\cdot \text { Lower freight expenses }\end{array}$ \\
\hline (7) & $\begin{array}{l}\text { Net Income } \\
=(3)-(4)-(5)-(6)\end{array}$ & Increase & $\begin{array}{l}\text { Increased Revenue (IR) } \\
\text { Cost Reductions (CR) } \\
\text { Employee Productivity } \\
\text { (EP) }\end{array}$ & - Increase in net income \\
\hline
\end{tabular}

(Source: Model developed by author)

2009), and (d) unstable scheduling based on short term demand predictions with the possibility of last-minute adjustments (Lambert, 2008). Service jobs are often stressful (Cordes and Dougherty, 1993; Singh, 2000; Rapp et al., 2015) because of the high intensity and frequency of interpersonal contacts and the continuous need to interpret and shape the expectations of service recipients (Susskind et al., 2003). Also, service employee simultaneously needs to display emotions specified by the organization (Hochschild, 1983). Service employees have dual responsibilities, namely, to perform the tasks they are responsible for in a technical manner, and at the same time do this in a customerfocused, marketing-like way as part-time marketers. Service employees often encounter misbehaving 
Table 2. Good Jobs Strategy in Retail: An Illustration of Financial Evaluation Model

\begin{tabular}{|c|c|c|c|c|c|}
\hline $\begin{array}{c}\text { Sr. } \\
\text { No. }\end{array}$ & Net Income Calculation & $\begin{array}{c}\text { GJS } \\
\text { Performance } \\
\text { Drivers }\end{array}$ & $\begin{array}{c}\text { Base } \\
\text { Case } *\end{array}$ & $\begin{array}{c}\text { New } \\
\text { Case** }\end{array}$ & $\begin{array}{c}\text { Net } \\
\text { Impact }\end{array}$ \\
\hline$(1)$ & Sales Revenue & IR & 100 & 101 & 1.00 \\
\hline$(2)$ & COGS (Cost of Goods Sold) & CR & 85 & 84.99 & $(0.01)$ \\
\hline$(3)$ & Gross Profit = (1) - (2) & IR & 15 & 16.01 & 1.01 \\
\hline$(4)$ & Selling Expense & CR & 2 & 1.98 & $(0.02)$ \\
\hline$(5)$ & G \& A (General \& Administrative) Expense & EP & 4 & 3.96 & $(0.04)$ \\
\hline$(6)$ & Logistics Expense & EP & 3 & 2.97 & $(0.03)$ \\
\hline$(7)$ & Net Income & IR & 6 & 7.1 & 1.10 \\
& CR $-(4)-(5)-(6)$ & EP & & & \\
\hline$(8)$ & Increase in Net Income (\%) & & & & $\mathbf{1 8 . 3}$ \\
\hline
\end{tabular}

(Source: Calculated by author)

(All figures are in millions of US Dollars)

${ }^{*}$ Pre Good Jobs Strategy Deployment

** Post Good Jobs Strategy Deployment

customers (Reynolds and Harris, 2006) and have to cope with conflicting job demands (Luria et al., 2014) and highly controlled jobs (Rosenthal, 2004).

\subsection{Workforce Stability}

A stable workforce of skilled, experienced and knowledgeable employees is driver of high quality service and long-term service relationships in most service settings (Bendapudi and Leone, 2003). A major disruptor of workforce stability is employee turnover which, together with high process cost of turnover, can lead tothe depletion of stocks of relational, human, and social capital (Holtom and Burch, 2016) of the organization, thereby negatively affecting customer outcomes (Staw, 1980). Relational capital is built through frequent, long-term, and trustworthy interactions between customers and employees, and cannot be easily replaced (Hunt, 1997). Employee turnover also depletes an organization's knowledge base of both explicit knowledge (i.e. intra-organizational knowledge readily available through procedures, policies, trainings and other formal mechanisms) and tacit knowledge (i.e. knowledge learned over time through experience and practice), affecting an organization's ability to deliver services and maintain employee-customer bonds at pre-turnover levels (Kacmar et al., 2006).

\subsection{Employee Turnover}

Employee turnover results in the alignment issue of novice employees with loyal customers, with the former lacking the knowledge of organizational processes necessary to provide satisfactory services (Hausknecht et al., 2009). Employee turnover also causes overall operational disruption and additional costs associated with it (Hausknecht and Trevor, 2011). A study of company-owned Burger King's found that increases in turnover among crew members led to longer customer wait times and higher food wastage (Kacmar et al., 2006). Chen and Sandino (2012) reported that employee turnover is associated with increased rates of theft in retail stores. Repeated high-quality interactions with customers enable employees to understand customer needs and preferences and better anticipate future needs (Bendapudi and Leone, 2003). Thus, employee turnover and departure can disrupt customer loyalty by impairing customer service levels and weakening brand attributes (Hausknecht et al., 2009; Subramony and Holtom, 2012; Holtom and Burch, 2016). 


\subsection{Employee Engagement}

Organizations strive to create environments in which employees can thrive, recognizing that highly engaged and passionate employees lead to delighted and loyal customers (Verhoef et al., 2009). Engaged workers are more productive, provide better service, and are less likely to jump ship - an especially big deal in retail, where turnover in 2016 averaged 65\% (Ton, 2017a). Employee engagement is an important driver of organization performance as a Towers Perrin survey of 90,000 employees in 18 countries reports that 80 percent of employees were either not fully committed or disenchanted or disengaged with their work. It was also found that companies with the most engaged employees had a 19 percent increase in operating income, while those with the lowest levels had a 32 percent decline (Schwartz, 2011).

Active disengagement at work costs the United States $\$ 450$ to $\$ 550$ billion annually (Gallup, 2017). With human capital investments such as training can help replenish human capital (Van Iddekinge et al., 2009). However, building the knowledge-base of newcomers takes time and attention away from tenured employees, shifting them from an external customer-focused mindset to an internal focus on resource building (Kacmar et al., 2006; Batt and Colvin, 2011). It is estimated that turnover costs organizations about one-fifth of a worker's salary (Boushey and Glynn, 2012). There is a negative relationship with turnover and customer-service outcomes such as customer satisfaction and perceptions of service quality (Holtom and Burch, 2016). There exists significant bivariate correlation between turnover and negative customer outcomes (Ryan et al., 1996; Detert et al., 2007; Cooil et al., 2009; Van Iddekinge et al., 2009).

\subsection{HRM Practices}

Prior research shows connection between employee well-being and employee retention and engagement (Gilsdorf and Hanleybrown 2017). Some business case studies show that businesses with happy, healthy, and stable employees can ultimately be more profitable than their competitors (Scott and Spievack, 2019). HRM practices typically include structured selection, skill-training, performance management, competitive pay, job security, employee voice, and empowerment. HRM systems refer to "combinations of HRM practices aimed at simultaneously influencing all or most of the workforce characteristics related to firm performance (Subramony, 2009). HRM systems can signal to employees how much the organization values effort, resulting in employees engaging in behaviours to reciprocate those efforts (Sun et al., 2007). HRM systems influence the acquisition and development of human capital resources (i.e. the collective levels ofknowledge, skills, and abilities of employees), facilitate the creation of customer and employee-focused organizational climates, and affect employee attitudes and behaviors, thereby contributing to organizational effectiveness in the form of employee, customer and organizational performance (Subramony and Pugh, 2015).

\subsection{Types of HRM Systems}

Organizations can also vary in the focus of their HRM systems and whether an organization emphasizes control or commitment (Arthur, 1994). Different HRM systems are likely to be effective for different types of service jobs. Control-based HRM systems involve emphasis on rules and procedures, punishment, and close employee monitoring whereas commitment based HRM systems reflect investing in training, career opportunities, higher wages, and employee benefits. Encouraging job satisfaction and organizational commitment remain one of the most critical potentials of enhancing organizational performance towards attaining sustainable competitive advantages (Kasemsap, 2017). Organizations with commitment based systems capitalize on improving employee skills, motivation, and opportunities to contribute, in order to improve organizational performance on measures such as turnover (Appelbaum et al., 2000; Lepak et al., 2006).

Organizations that adopt a control system, increase employee efficiency and productivity through close enforcement of company policies and regulations. Control-based HRM would in effective in 
positions requiring standardization, automation, and quantitative output; while commitment-based systems will be more effective in jobs requiring autonomy, discretion, and customer relationships. Both control and commitment based HRM systems could co-exist within one organization, and could drive service performance (Su et al., 2018). It is mainly because, standardized scripts make it easier for new employees to provide consistent customer service, while training and empowerment help build the employee-commitment necessary to follow processes and deliver these service levels (Subramony et al., 2017).

\subsection{Investment in HR and Operations}

Some companies start to invest heavily in their HR by paying them above industry average and providing an engaging work environment. To make the investment in HR viable, companies have to combine it with changes in the operations. With better operations, companies reduce complexity and waste in the process and focus more on customer interactions and needs. These operational practices work best with a capable and motivated workforce and hence they require investment in people (Boudreau et al., 2003). Investment in HR allows for excellent operational execution, which boosts sales and profits, which allows for a larger HR budget, which results in even more investment in employees.

It is evident from the extant literature that there is only limited research into various performance drivers of Good Jobs strategy. Although prior research lists the benefits of Good Jobs strategy, there is lack of research to explain the process of Good Jobs strategy in holistic way to emphasize complementary relationship of HR and operations (i.e. building blocks of Good Jobs strategy). Hence, this research focuses on investment in people and operations (i.e. Good Jobs strategy building blocks) and develops various frameworks and models for synthesising and evaluating value creation processes for employees, customers and the organisations. The findings of this research contribute to the knowledge by highlighting the process of Good Jobs strategy along with its supporting elements and developing various financial models.

\section{GOOD JOBS VERSUS BAD JOBS}

Good Jobs and Bad Jobs companies are radically different in terms of investment in HR and operational systems for enhancing their people and operations stability. The salient features of Good Jobs and Bad Jobs companies are explained below:

\subsection{Good Jobs}

Good Job companies see employees as a sales driver rather than a cost driver therefore investment in HR is priority for them. Good Jobs companies establish "virtuous cycle", where employees are not viewed as a cost to be minimized but as a driver of sales and profits. At Good Jobs companies, headquarters don't make functional decisions without considering the impact on the employee productivity and the level of customer service they can provide. As communication is two-way, and headquarters incorporates stores' input, managers feel like owners and hence they take long term decisions. They believe that developing their employees and taking care of customers are their most important tasks, and the operating system is designed accordingly.

At Good Job companies, employees are cross-trained and also have a lot of discretion (e.g., in ordering inventory, helping customers. and process improvement). Employees can increase their productivity when they apply discretionary levels of effort to their work tasks (Colvin et al., 2001). Good Jobs strategy emphasizes promoting managers from within for better acceptance, productivity and alignment with organization culture. Employees of Good Jobs companies also expect their employers to respect their time and knowledge and to allow them to shine in front of customers. At Good Jobs companies, employees are empowered to make decisions and rewarded for their productivity 
and contributions. It is found that increasing a store's average employee hours, decreasing schedule variability, and reducing employee turnover could lift sales productivity by more than $20 \%$ (Ton, 2017).

\subsection{Bad Jobs}

Bad Job companies believed that the only way they could guarantee low prices to customers was to operate with employees who were paid as little as possible, because labor was such a big part of their overhead. Employees were not just poorly paid, but poorly trained. In retail, they often didn't know their job schedule until the last moment. Morale was low and turnover was high. Customer service was largely nonexistent. These companies viewed their employees "as a cost that they tried to minimize." Bad Jobs companies are struck in "vicious cycle", where employers are constrained with labor budget, and hence they are hesitant to invest in employee training or other benefits that increase retention and boost sales. As labor budgets are set as a fraction of sales, labor budgets take a hit when sales drop. Hence, managers cannot increase staffing levels, even when they know it will make the business more profitable; thus, the vicious cycle continues. This problem is aggravated as managers' incentives and evaluations are linked to their ability to minimize employee costs as a fraction of sales. Hence, to make rapid adjustments during period of fluctuating consumer demand, first soft target is to reduce men power. Chaos, low morale, high rates of turnover and absenteeism are the norm at Bad Jobs companies.

Bad Jobs companies pay low wages, and hence they have workforce instability and are often understaffed. The low wages as well as financial stress can lead to a range of sub-optimal employee actions ranging from simple inattention to weak problem-solving and safety failures (Meuris and Leana, 2015). In this scenario their managers end up performing other employee tasks themselves. Bad Jobs companies spent great amount of time on routine activities (e.g. constant display changes in retails that take hours to set up and break down) that could have been spent on much higher value added work like helping customers and trying out process improvements. These companies have frequent staffing, equipment, and customer-service related problems, and thus, managers have little or no time to train employees or give feedback. Employees also spend great amount of time to resolve critical equipment or technology issues (e.g. breaks down of scan guns, refrigerators, or scheduling software in retail stores) or just go without it for days or weeks. There is a strong correlation between indicators of Bad Jobs, such as high turnover (40\% to 120\%) and frequent last-minute schedule changes, and costly operational problems, such as stock-outs, inventory shrinkage and inaccuracies, and low customer conversion rates (Ton, 2017).

\section{GOOD JOBS STRATEGY: SYNERGY OF HR AND OPERATIONS}

Human resources management (HRM) and operations management (OM) historically have a longhistory of separateness. Yet, operations and human resources are intimately related at a fundamental level in virtually all business environments. Operations management $(\mathrm{OM})$ is a discipline that originated to solve management problems in a manufacturing environment, but now practitioners have begun to adapt the knowledge of the field to also support service operations by eliminating waste and improving efficiency. The Good Jobs strategy emphasizes complementary relationship of HRM and OM. Short- and long-term investment in employees with higher wages, training, and stable work schedules enhances employees' performance. Operational choices increase employees' productivity, contribution, and involvement in continuous improvement. Service companies can enhance its performance by helping employees to understand the implications of the better OM choices for their work and then making investment in better HR practices to motivate them to act accordingly.

Decent wages are necessary for many companies that are stuck in a vicious cycle of Bad Jobs, bad operations, bad customer service, low productivity, and high costs. However, higher wages alone are not enough to break this vicious cycle to enhance productivity and boost sales. It should be accompanied by other operational changes; otherwise, higher wages will likely reduce company profits 
and will not turn Bad Jobs into Good Jobs. Good Jobs strategy breaks "vicious cycle" of poor sales and subsequently cost cutting by staff reductions and creates "virtuous cycle" of high sales, quality employee programs and efficient operations by investing in HR and enhancing operational choices. The Good Jobs strategy creates superior value for employees, customers, company and investors by combining investment in HR with better operation system choices to increase employee productivity, contribution, and motivation (Figure 2).

\subsection{HR Investment}

Good Jobs strategy relies on a capable, reliable, and motivated workforce as it is a greatest resource for any company. There are much inefficiency encountered with mediocre workforce in the form of higher operating costs, lower quality, worse customer service, and less responsiveness and adaptability. Good Jobs strategy companies inculcate a culture that dynamically embraces the organization's values (e.g. trust, authenticity, caring, transparency, integrity and learning), such that employees feel empowered to act on those values, unencumbered by rules and bureaucracy. These companies devote considerable time and resources to train employees and empower them to address consumer concerns.

Additionally, they strive to create fun, and productive work environments in which people are highly engaged, listened to, and respected as capable contributors. The most intermediate impact of Good Jobs strategy is a reduction in turnover, which is valuable because it saves on recruiting and training costs, preserves organizational knowledge and creates relationships of trust among employees, and avoids lower productivity while new hires become proficient. When employees see their jobs as long-term career opportunities, rather than short term stints, their satisfaction with their organization increases which, in turn, reduces turnover rates (Grewal et al., 2017). Investing in people with better wages as suggested by Good Jobs strategy may seem expensive, but the alternative - a poor-performing operation - is much costlier. To avoid incurring endless high penalties for mediocre workforce, it is better to invest in HR, in terms of well-paid, well-trained and well-motivated employees. Employees are assets that require investment and care; they should not be treated as cost centres to be curtailed (Cascio and Boudreau 2011; Ton 2014).

Hiring the right people, offering decent wages, setting high performance expectations, and effective training ensures that empowered employees make the right decisions for customers and the company. One of the drivers for McDonald's high productivity is related to the training opportunities the company offers its managers and franchisees through Hamburger University (Chase and Apte, 2007). Providing higher average compensation can enhance retention and attraction, provide a higherquality workforce, and thus enhance the probability that when skills are used, they will be applied proficiently (Milkovich and Newman 2002). For such companies, a great customer experience is integral to their culture, so the responsibility for creating it is not relegated or limited to any particular individual or department. Creating a superior customer experience differentiates companies (Grewal et al., 2009; Verhoef et al., 2009). Investment in people enhances employee accountability; increases expectations and ownership and hence, encourages employees to innovate and to improve service and sales. Following illustration explains how decreased investment in HR caused performance of Home Depot to deteriorate.

\subsubsection{Home Depot}

In 2000, Home Depot used "flexible" approach, when former GE executive Robert Nardelli became CEO. Accordingly, he cut staffing levels and increased the percentage of part-timers to reduce costs and boost profits. Those moves achieved both goals immediately. However, it involved replacing knowledgeable full-time employees with part-timers who did not know as much about home improvement and the store's products and so could not help customers effectively. Hence, this shortterm approach eventually caused Home Depot's excellent customer service - the company's claim to fame and, arguably, primary source of competitive advantage -to suffer, customer satisfaction to plunge, and same-store sales growth to drop and even go negative in some years (Ton, 2012). 


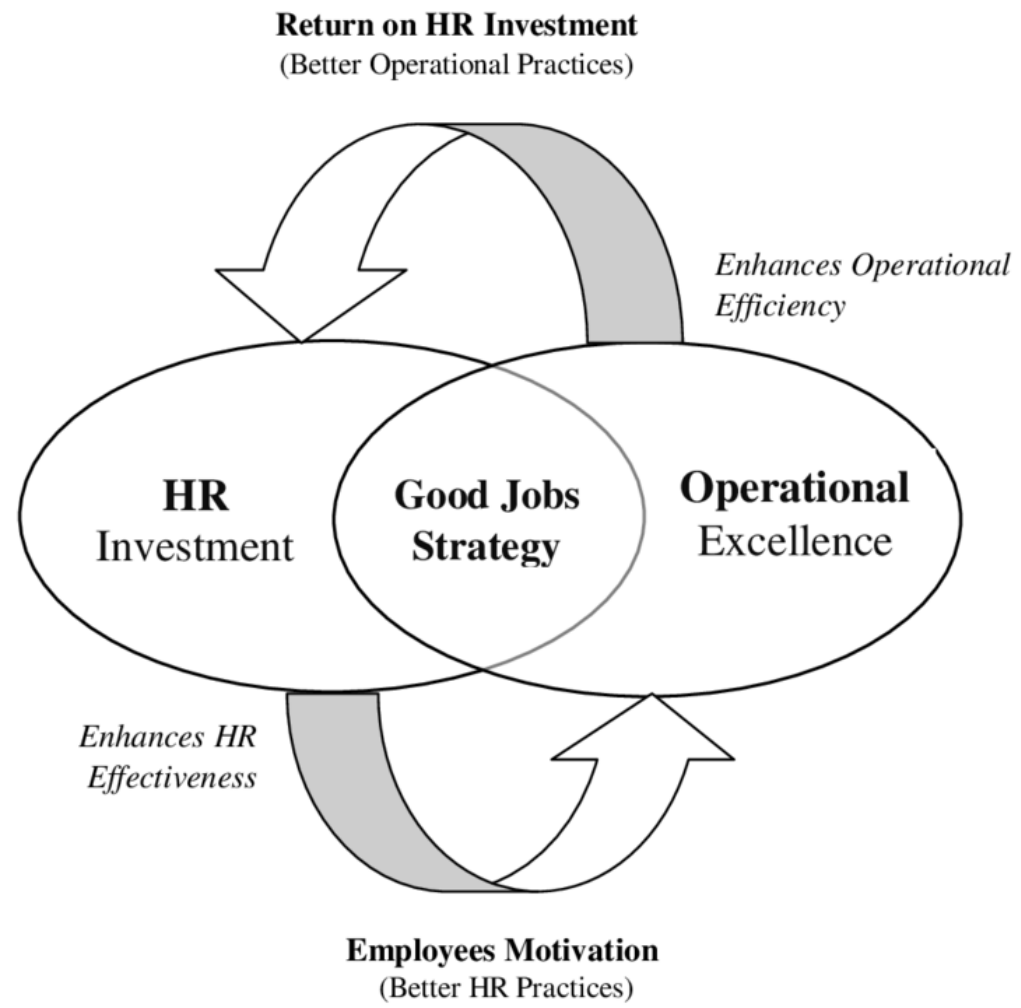

\subsection{Operational Excellence}

Just treating employees better and paying decent wage however, will not boost a company's competitiveness. It requires a radically different OM system - one designed to increase workers' productivity, motivation, and overall contributions and better serve customers' needs. Service companies have many problems and challenges that can be addressed by operations management methods. Hence, they try to optimize their internal processes with the eventual goal of achieving "leanness" and increasing the quality of their services. Continuous improvement methodologies such as Lean, Six Sigma, Lean Six Sigma, TQM (Total Quality Management), Kaizen, TPS (Toyota Production System) have been deployed in service organizations. The deployment of Lean, Six Sigma, and Lean Six Sigma results in competitive advantages for retailers (Madhani, 2020a, Madhani, 2020b). In service sector, company's operational system has direct impact on employees' performance if it is wasting rather than maximizing their skills and enthusiasm.

\section{GOOD JOBS STRATEGY: MAJOR BUILDING BLOCKS}

To thrive in today's competitive markets, service companies need to offer a better customer experience, by improving both the operations as well as employee experience. When service companies are full of 
operational problems, everyone gets frustrated and hence results in a poor customer experience. Good Jobs strategy is a model for empowering and investing in frontline employees in service industries and revamping operations to support those employees, helping them be more productive and serve customers better. Higher investment in HR pays off in people stability and operational excellence. Toyota shares the values of Good Jobs strategy companies as it is known for worker-friendly policies, such as no layoffs. According to Toyota philosophy, customers come first, employees are the most important resource, and the focus is on continuous improvement. In service companies, the desire to show results quickly lead to short term decisions. Until work processes, work schedules, workloads, employee turnover, and absenteeism have been addressed, companies will find it hard to get competitive advantages. Hence, there is need to implement operational process improvements along with supporting investment in HR. When operational issues are handled by poorly paid, poorly trained, poorly motivated employees and under-staffed employees, the consequences for operational execution can be severe.

As shown in Figure 3, Good Jobs strategy is a system and all the parts must work for better synergy. The system consists of investment in HR (i.e. effective hiring and training process, better compensation, high performance standards, and meaningful career paths), and better operating system. Operational practices of stabilization, standardization, cross-training and creating slack i.e. major building blocks of Good Jobs strategy (Ton, 2020) are explained below:

\subsection{Simplify}

Simplification provides small but meaningful ways to improve work, engagement, and customer service. Simplified process enables employees to be knowledgeable about products and services, which help them to make better decisions for customers and to provide input for improvement. Thus, simplified operations maximize value for their customers, minimize mistakes, lower costs, and boost sales and improve employee productivity and motivation. High product variety doesn't necessarily increase sales but makes the operating environment more complex for store employees. Simplified process emphasizes "everyday low prices" rather than frequent promotions. Better training and reducing the number of product varieties (i.e. SKUs) can help enhance store employees' knowledge further. Knowledgeable employees can educate their own customers about the products, which increases the sales stemming from these interactions (Ton, 2012).

Processes need to stabilize for creating predictable and repeatable outputs. Stabilization focuses on process problems and identifies various issues related to customers and accordingly streamlines products, promotions, and services to maximize customer satisfaction and employee productivity. Simplification of processes is necessary for better outcome in service companies as over time processes tend to become more complex. Periodically reviewing processes and making an effort to streamline them leads to more efficient operations. Simplifying operations and reducing variability allows companies to offer more predictable work schedules. Unstable work schedule caused by unpredictable and last-minute changes in work hours create challenges for arranging child care and disrupt family life in other ways, leading to employee stress and hence higher turnover (Lambert and Henly, 2009; Williams and Huang, 2011; Henly and Lambert, 2014).

\subsection{Standardize}

Standardizing routine processes, inviting employee input, and empowering them to improve those standards will result in better customer service and cost reduction for service companies. Standardization also contributes to process simplification and gives employees clear expectations for their performance and enables them to focus more on the job requirement. Standardization with empowerment further increases employee motivation by showing respect for their time and their judgement. Standardization facilitates a lean, efficient, and functional workplace as its primary focus is to streamline or simplify work. Toyota is renowned for combining standardization with 
empowerment. Standardized work reduces wastes and drives employee engagement, quality, and productivity (https://goodjobsinstitute.org).

Standardized processes are crucial in service companies as often the same processes are executed differently across various units and, sometimes, even within the same unit. Identifying the most efficient way to complete a process and making sure that all similar processes are completed in the same way results in significant operational efficiencies. Standardizing routine operations (e.g. the unloading of trucks, shelving, and cleaning etc.) and enhancing frontline employee contributions by empowering them will increase process efficiency. Taking input from employees, and empowering them for merchandising (how much inventory to hold, which products to stock, how to display them, and so on), and solving customer problems will improve their work (Bonini et al., 2017). Empowerment increases motivation and helps employees contribute to higher sales.

\subsection{Cross-Train}

Cross-training means that employees will be trained to complete a variety of job functions. Employees perform better if they are properly skilled. By identifying the skill requirement of each employee (e.g. via a skills-matrix) and constantly improving them would result in employees completing their jobs faster and in better quality. Ensuring proper skill levels and mixes is vital as having operations teams consisting exclusively of experts might be not effective and too expensive. Only if employees have a broad skill set, they can perform a flexible range of tasks. To enhance this skill set, cross-training is crucial. Cross-training helps in meeting the fluctuations in demand as well as avoids problems as employees cross-trained in several positions have better understanding of operations and enhances flexibility. With improved flexibility it is easier to manage unbalanced workload when it requires less help in one area and additional help in another. Cross-training enables employees to use their judgment to move between tasks to best serve the customer. Cross-training of employees can greatly increase company's flexibility and responsiveness (www.gaebler.com).

It is important to train employees to perform both customer-facing and non-customer facing tasks so that they can vary what they do depending on customer traffic - and train them in a way that ensures ownership and specialization. Cross-training means more-predictable work schedules, balanced work load, higher motivation, better teamwork, employees who are more responsive to customer needs, and higher productivity (because there's less employee downtime when traffic is slow) and thus provides tremendous benefit to company. Cross-training of employees can serve customers better while also increasing their skills (Ton, 2012).

\subsection{Creating Slack}

When companies operate with slack, employees have the spare time; hence, they can devote maximum time in understanding customer needs and identifying and solving their problems. To stay efficient, service organizations should continuously monitor workload and balance it as needed (e.g. transferring some workload by using slack). Unpredictable work schedule and significant misbalance of workload can cause employee dissatisfaction. Hence, it is necessary to keep slacks by providing more men power than the expected normal workload so that it is possible to meet demand at peak times. Operating with slack lets employees do their works without making mistakes, deliver great service, and have time to identify and communicate ideas for improvement (Ton, 2017b). It enables companies to cut costs and continuously improve. This option requiresmore employee investment, but it also makes that investment possible, by increasing employees' productivity and contributions. 


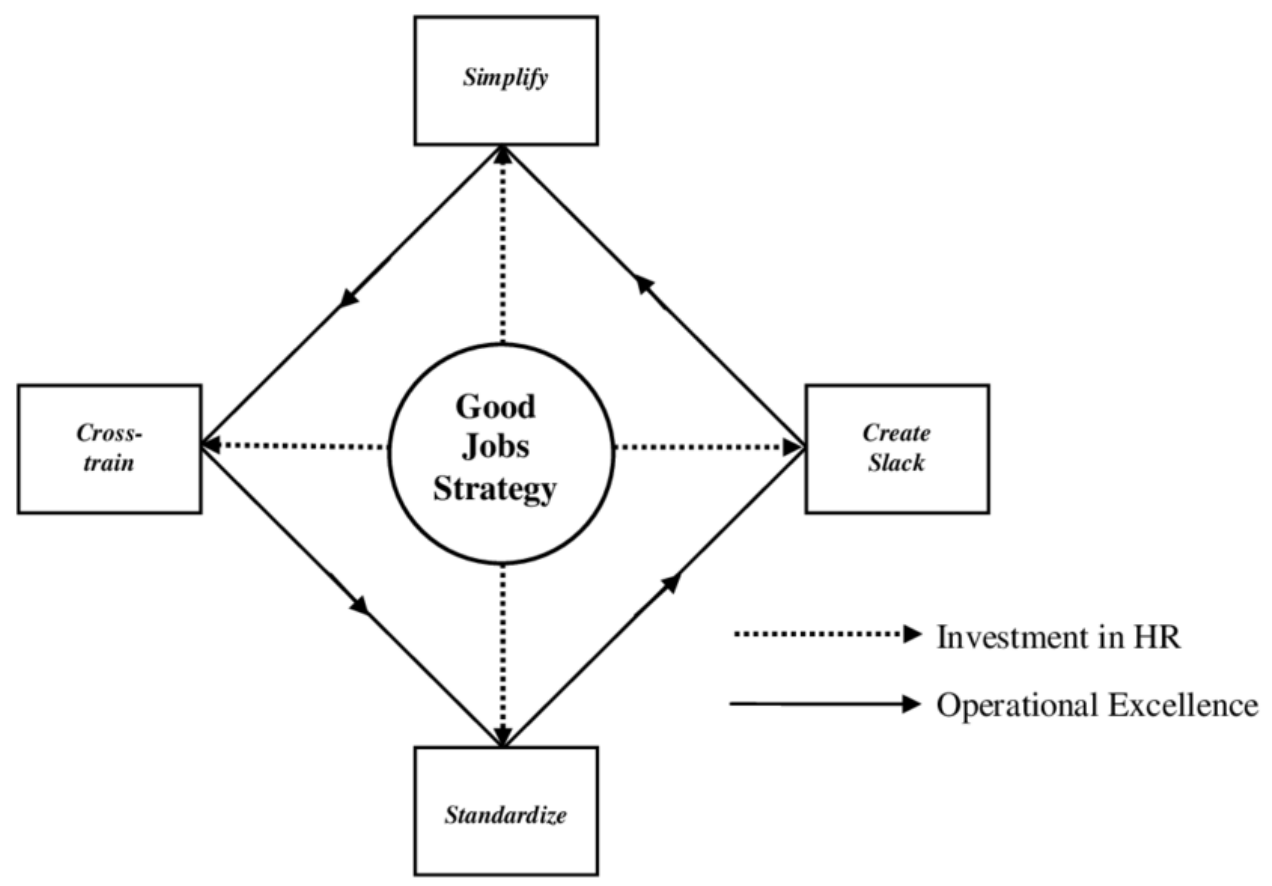

\section{SUCCESSFUL DEPLOYMENT OF GOOD JOBS STRATEGY: VARIOUS ILLUSTRATIONS}

Various companies in service sectors have successfully deployed Good Jobs strategy. Following illustrations explain how these companies deployed Good Jobs strategy and transformed the companies to enhance overall performance.

\subsection{Quest's Diagnostics}

Quest Diagnostics, a provider of medical diagnostic services, suffered from high employee turnover and a $12 \%$ absentee rate. $60 \%$ of call centre employees left within a year, resulting in up to $\$ 10.5$ million annually in direct turnover costs (Ton, 2017b). Supervisors spent most of their time answering calls that inexperienced reps couldn't handle, and customers were frustrated. The main reasons for the employee turnover were low pay and lack of career paths. The work was more complicated than that at a typical call centre, yet the pay was about the same, and it didn't rise as employees acquired new skills. To address these issues, Quest deployed Good Jobs strategy in July 2015. It has made large investment in HR by raising wages, offering a clear career path to employees and stabilizing its workforce to improve the performance of its call centres. Quest also implemented operational improvements such as cross-training and empowering employees.

Quest implemented step-based pay and a higher starting wage and provided clear career paths. To subsidize the higher wages, it has identified and eliminated waste from the process. Quest found that certain services provided by phone could be offered in other ways, ones that both lowered costs 
and increased customer satisfaction. For example, many physicians preferred receiving normal test results by fax rather than by phone. Many patient calls concerned location, hours, or scheduling things that don't require a rep's expertise - so Quest made that information more accessible online. Quest has seen significant performance improvements that have delighted customers. By simplifying and focusing on the most important value it offered customers - important medical information as quickly and accurately as possible - Quest cut costs and improved service. Since then it has seen a $20 \%$ reduction in its call-transfer rate (calls that must be passed on to someone else because the first rep can't field the question) and a $40 \%$ improvement in how quickly calls are answered. By March 2017 turnover had dropped by 53\%, absenteeism by 66\%. Within eight months of implementation, call centre reps had submitted 1,556 ideas for improvement, 1,001 of which have been implemented. Of $\$ 2$ million in savings, \$1.2 million came from those ideas (Ton, 2017c).

\subsection{Walmart}

Walmart, world's largest retailer has deployed Good Jobs strategy to enhance employee satisfaction and productivity, reduce their turnover and enhance customer experience. Walmart raised frontline workers' wages, introduced paid time off and improved benefits as low wages have difficulty in attracting the right talent for jobs as well as holding people for any length of time. Walmart is investing more in training and is streamlining operations to help store workers be more productive. Walmart has simplified the assortment in parts of it stores. Walmart created new work standards called "One Best Way" to manage inventory, scheduling, setting shelves etc. With standardization, Walmart was able to get routine tasks done faster by creating efficiency and thus associates spend more time serving customers. Walmart is also investing in cross-training so that associates can perform a wider range of tasks, and keeping slack - staffing stores with more labor hours than the expected workload calls for.

Walmart has introduced a program called Pathways to make a better induction process for new hires (i.e. associates). This program gives entry-level associates training and mentoring over their first few months. Walmart has established 200 "academies", where the training lasts anywhere from two days to a week. Academies are dedicated facilities where associates in roles such as frontline supervisor, department manager, and assistant manager receive training. Training covers retail fundamentals and area-specific skills. Training is designed to teach skills crucial for retailing, including customer service, merchandising, teamwork, and communication. After successfully completing the program people receive a pay increase, information about the career paths available to them at Walmart, and a clear picture of what experiences and skills are required to grow with the company. With Pathways program, every manager now has the ability to get into HR metrics - to know the number of open positions, turnover rates, who's completed training, and who's due to be trained.

All associates have the ability to earn a bonus through "My Share". Walmart is tying attendance to its "My Share" bonuses paid to store employees, to incentivize them to show up on weekends and holidays. Walmart has deployed technology to increase associate productivity. Walmart associates were using a Telxon- a wireless barcode scanner for checking prices and managing inventory, which has been around for a long time. They've now got better tools i.e. TC70 mobile touch computers (Prokesch, 2017). These android based enterprise-class handheld computers seamlessly communicate and access information in real-time in order to work more efficiently and better serve customers. The customer experience has significantly improved because of the remodelled, cleaner stores; better-trained associates who can serve customers more effectively; better in-stock positions; and the ability to get through checkouts quicker. These efforts are bearing fruit as Walmart's same-store sales jump 4.5\% during the second quarter (Q2 2019), and the growth was the highest in more than a decade (Bach et al., 2019).

\subsection{QuikTrip}

QuikTrip (a Tulsa, Oklahoma based US chain of over 800 convenience store/gas stations that competes with the 7-Eleven retail store chain) has deployed Good Jobs strategy. QuikTrip is more selective 
during hiring and deploys centralizes recruiting in each city, and experts use structured interviews and cognitive tests. New hires must "graduate" from training. However, about $20 \%$ of full-time trainees and $14 \%$ of part-time trainees fail to graduate (Ton, 2017b). Employees are cross-trained so they can do different jobs and also make merchandising decisions for their own stores. At QuikTrip, products don't remain in the back room, and in-store promotions always take place, as they're supposed to. The wages and benefits at QuikTrip are so good that the chain has been named one of Fortune's " 100 Best Companies to Work For" every year since 2003 (Ton, 2012).

At QuikTrip, part-time employees receive 40 hours of training and full-time employees receive two weeks - not just in checking out customers but also in brewing coffee, ordering merchandise, sweeping floors and the parking lot, cleaning bath- rooms, and stocking coolers, freezers, and grills (Ton, 2012). Once hired, QuikTrip's store employees are held to high standards and peer pressure helps maintain standards, because part of everyone's pay is tied to the store's customer-service score, and full-timers enjoy profit sharing. With human-centered operations strategies, QuikTrip provides substantial growth opportunities as all store managers are promoted from within. QuikTrip's 13\% turnover rate among full-time employees is substantially lower than the $59 \%$ average rate in the top quartile of the convenience store industry. QuikTrip maintains a force of hundreds of employees who do not report to a specific store but are ready to fill in for people who get sick, take a vacation, or have an emergency (Hanna, 2011). At QuikTrip, employees from every position regularly discuss problems and identify opportunities for improvement (Ton, 2012).

\subsection{Costco}

Costco, a wholesale-club chain retailer has deployed Good Jobs strategy. Costco offers higher pay, fuller training, better benefits, and more-convenient schedules to employees than their competitors. Store employees earn about $40 \%$ more at Costco than at its largest competitor, Walmart's Sam's Club (Ton, 2012). About $98 \%$ of store managers are promoted from within, and many executives at these companies started out in the stores (Ton, 2012). All these actions have positive result as turnover for employees who stay at Costco for more than a year is only 5.5\% (Ton, 2012). Costco coordinate product introductions so that new items are brought out at staggered times, smoothing out workloads at stores. Costco store managers are empowered to display merchandise and provide input into the merchandising system. A merchandising algorithm does provide insight into what should be stocked, but the store managers are on the floor every day, putting their own and their employees' judgement in problem solving, critical thinking, and creativity skills (Ton and Kalloch, 2017). Costco had the highest Good Jobs scores of 9.2 among US public food retailers. Good jobs score comprises of customer score, employee score and productivity score. The three components measure level of customer satisfaction, employee satisfaction, and productivity (Ton, 2015).

\subsection{Mercadona}

Mercadona, Spain's largest supermarket chain has deployed Good Jobs strategy. Mercadona uses frontline input when standardizing processes such as the handling of deliveries and schedules activities such as display changes, equipment maintenance, and product introductions when traffic is likely to be low. When Mercadona developed a new decentralized-ordering system, it implemented employee suggestions such as removing information that workers found irrelevant and confusing. Mercadona provides the opportunity to employees to thrive in front of their customers every day.

Mercadona, invested $€ 600$ million between 2005 and 2008 to install the most up-to-date logistics and in-store retail technologies. These projects were implemented smoothly because their employees were motivated and highly engaged in the deployment process. During the process no one was laid off - so the employees didn't see the new infrastructure or technology as the threat. They were well trained in the new technology and empowered to help customers. The new in-store technologies were developed not just to increase efficiencies but also to make the customer experience better. Despite a large expense and no downsizing, Mercadona's productivity went up and its financial performance 
improved significantly. Sales per employee went from 179,142 Euros in 2005 to 232,260 Euros in 2008 (Ton and Kalloch, 2017).

Mercadona emerged from the 2008-09 financial crisis with higher market share because it was able to cut prices by $10 \%$ while maintaining profitability. Many of its cost-cutting ideas came from employees. They knew their customers and were empowered to identify products and processes that could be improved or eliminated - and they knew top management would take their insights seriously. They also knew the company wouldn't use their cost-cutting ideas as an excuse for layoffs. At Mercadona, every new employee receives four weeks of training (that costs the company $\$ 5,000$ ), during which they learn how to manage a particular section of store, perform inventory checks, order merchandise, replenish products from backrooms, and check for product defects or other problems. As a result of this cross-training, employees have more-predictable schedules and are always busy (that is, more productive), and customers get faster service from more-knowledgeable employees. At Mercadona, managers at headquarters in charge of specific processes routinely visit stores and talk to employees (Ton, 2012).

Mercadona works with vendors to create shipments that can be quickly shelved. Its logistics department gives stores short delivery windows (15 to 20 minutes) so that receivers know exactly when to be ready and don't waste time. Logistics sends the same driver repeatedly to a given store so that the parties can learn to work efficiently together (Ton, 2017b). Such actions allow Mercadona to give employees higher pay (thanks to increased productivity) and more-predictable schedules to employees by assigning work schedules a month in advance (thanks to a smooth and predictable workload) and to achieve low employee turnover. At Mercadona, employee turnover is mere $4 \%$ (Ton, 2012). If a store needs extra time because of its layout, the owner of the delivery process for the chain will adapt the process for that store.

Operational simplification (fewer products, no promotions, predictable deliveries, and so on) and the standardization of routine processes (such as unloading trucks, shelving, and cleaning) further reduce variability and make it possible to more accurately forecast workloads. Hence, even though customer traffic varies greatly throughout the day and week, (Daily transactions in one store ranged from 1,700 on weekdays to 3,000 on Saturdays), Mercadona was able to provide stable schedules (Ton, 2017b). Stable schedules also require cross-training so that employees can shift between customerfacing tasks (such as helping people find products and manning the cash register) and non-customerfacing ones (cleaning, restocking, and so forth) according to customer traffic.

All of Mercadona's employees are permanent, and more than $85 \%$ are salaried full-timers (Ton, 2012). All store managers at Mercadona are promoted from within. Specialists in areas such as produce, bakery, and cosmetics are empowered to order products, talk to customers to understand their needs, and improve their work. They have time for all this because Mercadona operates with slack. The specialists feel ownership of and are accountable for their area's performance. Mercadona, uses its employees' creative and problem-solving skills to suggest product, packaging, and transportation improvements that have already saved the company millions of Euros. Mercadona's store employees are empowered to order products and present them in a way that satisfies their customers and improves company performance. Empowering employees in these ways makes companies more responsive to local needs and preferences, it increases customer as well as employee satisfaction.

Mercadona offer fewer product varieties within its chosen categories (around 8,000 SKUs compared with the supermarket industry average of approximately 39,000) than rivals do (Ton, 2012). Hence, employees can be familiar with everything the store sells and make knowledgeable recommendations to customers. At Mercadona stores, each section is managed by a specialist who will gladly explain to shoppers why Mercadona has fewer products or does not carry particular products. Sales went up because simplifying operational execution allowed Mercadona to reduce prices even more and allowed employees to explain to customers why they were getting a better deal. At Mercadona, managers at head-quarters in charge of specific processes routinely visit stores and talk to employees (Ton, 2012). 


\subsection{Mud Bay}

Mud Bay, a pet retail store chain with 45 stores in the north-western United States, deployed a Good Jobs strategy, in 2014. For a smooth deployment, Mud Bay decided to launch eight weeks of small group discussions for 67 store managers and headquarters staffers, during which they discussed the Good Jobs strategy and how Mud Bay could benefit from it. The company then charged a team of six store managers and six home-office staffers elected by their peers, three district managers, and five top executives with creating a vision and strategy for the transformation. With this up-front effort generated companywide, store employees were excited enough to talk about the transformation with customers, who then felt even better about shopping at the Mud Bay (Ton, 2017c). Mud Bay raised wages by about $30 \%$, implemented an employee stock ownership plan (ESOP), increased the percentage of employees working over 30 hours a week (and hence receiving benefits) from $65 \%$ to $82 \%$, and had made many changes to its operations, from simplifying assortment to smoothing workload to standardizing processes.

The results of these changes were highly impressive: Mud Bay reduced employee turnover to $35 \%$, increased sales per square foot from $\$ 317$ to $\$ 394$, sales per employee hour from $\$ 133$ to $\$ 149$, inventory turnover from $6.8 \mathrm{X}$ to $7.5 \mathrm{X}$; and increased average annual same-store sales growth from $6.5 \%$ to $11 \%$. While other pet store chains have lost traffic to e-commerce, Mud Bay's sales keep growing as customers continued their loyalty. Moreover, stronger operations and motivated and capable employees enabled Mud Bay to adapt to customer needs much more quickly than before. Mud Bay also got higher customer ratings from customers as it seldom received fewer than five stars on Yelp (the largest 100 retailers' average: 3.2 stars) (Ton, 2017c).

\section{MANAGERIAL IMPLICATIONS, LIMITATIONS AND DIRECTIONS FOR FUTURE RESEARCH}

Good Jobs strategy is not easy to implement due to various reasons: In short term, some types of performance might temporarily decline. Costs might go up, owing to higher wages and bigger investments in training. Sales might fall as promotions are reduced. Turnover might increase as some headquarters employees might leave because they don't like the loss of control. Some frontline employees might not like the higher standards and quit. Hence, moving to a Good Jobs strategy requires patience and will most likely take years for its financial performance to improve significantly. However, in the long run, Good Jobs strategy improves performance of the service organization for sustainable competitive advantages. Hence, future research should focus on determining time-line required for successful deployment of Good Jobs strategy for big as well as medium sized companies. The models developed in the research may be used to compare deployment of Good Jobs strategy across various sectors or companies. This may offer more opportunity for other scholars to undertake empirical study in the field of Good Jobs strategy.

This conceptual research study has achieved its aim and objectives; however, as with any other study of this kind of qualitative research, it has certain limitations. The disadvantages of not using real life company data for empirical research and related statistical techniques add to the limitations of this research. Future research may focus on empirical research as well as case study methodology to quantify benefits of Good Jobs strategy in service sector companies.

\section{CONCLUSION}

There are millions of service jobs at retail stores, restaurants, education, health, social work, banks, real estate, call centres, hotels, recreation, media, communications, electricity, gas and water supply and day cares - but most of them are lousy and have been for decades. They offer few benefits, no career paths and hence considered as Bad Jobs. Conventional wisdom holds that Bad Jobs are the unavoidable 
price of low-cost service. However, this research emphasizes that way Bad Job companies run their service business, including treating their employees as replaceable commodities, is not sustainable.

The Good Jobs strategy also enables service organization to adapt to changes such as the economy's ups and downs better than their rivals and hence likely to offer financial and competitive advantages. The presumed trade-off between investment in employees and low prices can be broken. Research provides diverse illustrations of successful deployment of Good Jobs strategy by various companies. Highly successful companies in retails (such as Costco, QuikTrip, Mud Bay, Mercadona, and Walmart) as well as call centers (Quest Diagnostics) have pursued the Good Jobs strategy. They not only invest heavily in frontline employees but also have the lowest prices in their segments, solid financial performance, and better customer service than their competitors. Research develops various frameworks for successful deployment of Good Jobs strategy. Research also underscores that Good Job companies complement their investment in HR with operational practices that make the execution of work more efficient and more fulfilling for employees, lower costs and improved service for customers, and higher sales and profits for the company. The research also formulates various financial models for calculating benefits of Good Jobs strategy. Financial Measurement Model (FEM) identifies three types of performance drivers relevant to Good Jobs strategy: increased revenue (IR), cost reductions (CR) and employee productivity (EP). Based on these performance drivers, Financial Evaluation Model (FEM) quantifies impact of Good Jobs strategy on top-line and bottom-line of a company. 


\section{REFERENCES}

Ager, D.L., \& Roberto, M.A. (2013, Sept.). Trader Joe's. Harvard Business School Case.

Appelbaum, E., Bailey, T., Berg, P., \& Kalleberg, A. (2000). Manufacturing Advantage: Why High-Performance Work Systems Pay Off. ILR Press.

Appelbaum, E., \& Schmitt, J. (2009). Low-wage work in high-income countries: Labor-market institutions and business strategy in the US and Europe. Human Relations, 62(12), 1907-1934. doi:10.1177/0018726709349200

Arthur, J. B. (1994). Effects of human resource systems on manufacturing performance and turnover. Academy of Management Journal, 37(3), 670-687.

Bach, K., Kalloch, S., \& Ton, Z. (2019). The financial case for good retail jobs. Harvard Business Review, 26(June). https://hbr.org/2019/06/the-financial-case-for-good-retail-jobs

Batt, R., \& Colvin, A. J. (2011). An employment systems approach to turnover: Human resources practices, quits, dismissals, and performance. Academy of Management Journal, 54(4), 695-717. doi:10.5465/amj.2011.64869448

Bendapudi, N., \& Leone, R. P. (2003). Psychological implications of customer participation in co-production. Journal of Marketing, 67(1), 14-28. doi:10.1509/jmkg.67.1.14.18592

Bonini, J., Kalloch, S., \& Ton, Z. (2017). The GJS can take lessons from TPS. Harvard Business Review, 11(December). https://hbr.org/2017/12/the-gjs-can-take-lessons-from-tps

Boudreau, J., Hopp, W., McClain, J. O., \& Thomas, L. J. (2003). On the interface between operations and human resources management. Manufacturing \& Service Operations Management, 5(3), 179-202. doi:10.1287/ msom.5.3.179.16032

Boushey, H., \& Glynn, S. J. (2012). There are significant business costs to replacing employees. Washington, DC: Center for American Progress.

Bowen, D. E. (2016). The changing role of employees in service theory and practice: An interdisciplinary view. Human Resource Management Review, 26(1), 4-13. doi:10.1016/j.hrmr.2015.09.002

Bureau of Labor Statistics. (2015). Employment by major industry sector. U.S. Bureau of Labor Statistics. https://www.bls.gov/

Bureau of Labor Statistics. (2017a). Industry output and employment projections. U.S. Bureau of Labor Statistics. https://www.bls.gov/

Bureau of Labor Statistics. (2017b). National occupational employment and wage Estimates. U.S. Bureau of Labor Statistics. https://www.bls.gov/

Bureau of Labor Statistics. (2019). Employment Projections. U.S. Bureau of Labor Statistics. https://www.bls. gov/emp/data/occupational-data.htm

Bureau of Labor Statistics. (2020). Employees on nonfarm payrolls by industry sector and selected industry detail. U.S. Bureau of Labor Statistics. https://www.bls.gov/news.release/empsit.t17.htm

Butler, T. D., Armstrong, C., Ellinger, A., \& Franke, G. (2016). Employer trustworthiness, worker pride, and camaraderie as a source of competitive advantage. Journal of Strategy and Management, 9(3), 322-343. doi:10.1108/JSMA-07-2015-0058

Carré, F., Tilly, C., VanKlaveren, M., \& Voss-Dahm, D. (2010). 'Retail jobs in comparative perspective', Lowwage Work in the Wealthy World. Russell Sage Foundation.

Chase, R. B., \& Apte, A. M. (2007). A history of research in service operations: What's the bigidea? Journal of Operations Management, 25(2), 375-386. doi:10.1016/j.jom.2006.11.002

Chen, C. X., \& Sandino, T. (2012). Can wages buy honesty? The relationship between relative wages and employee theft. Journal of Accounting Research, 50(4), 967-1000. doi:10.1111/j.1475-679X.2012.00456.x 
Colvin, A. J., Batt, R., \& Katz, H. C. (2001). How high performance human resource practicesand workforce unionization affect managerial pay. Personnel Psychology, 54(4), 903-934. doi:10.1111/j.1744-6570.2001. tb00236.x

Cooil, B., Aksoy, L., Keiningham, T. L., \& Maryott, K. M. (2009). The relationship of employee perceptions of organizational climate to business-unit outcomes an MPLS approach. Journal of Service Research, 11(3), 277-294. doi:10.1177/1094670508328984

Cordes, C. L., \& Dougherty, T. W. (1993). A review and an integration of research on job burnout. Academy of Management Review, 18(4), 621-656. doi:10.5465/amr.1993.9402210153

Das, T. K., \& Teng, B. S. (2001). Trust, control, and risk in strategic alliances: An integrated framework. Organization Studies, 22(2), 251-283. doi:10.1177/0170840601222004

Demerouti, E., Bakker, A. B., Nachreiner, F., \& Schaufeli, W. B. (2001). The job demands-resources model of burnout. The Journal of Applied Psychology, 86(3), 499-512. doi:10.1037/0021-9010.86.3.499 PMID:11419809

Detert, J. R., Treviño, L. K., Burris, E. R., \& Andiappan, M. (2007). Managerial modes of influence and counter productivity in organizations: A longitudinal business-unit-level investigation. The Journal of Applied Psychology, 92(4), 993-1005. doi:10.1037/0021-9010.92.4.993 PMID:17638460

Eisenhardt, K. M., \& Schoonhoven, C. B. (1996). Resource-based view of strategic allianceformation: Strategic and social effects in entrepreneurial firms. Organization Science, 7(2), 136-150. doi:10.1287/orsc.7.2.136

Fombrun, C., \& Shanley, M. (1990). What's in a name? Reputation building and corporate strategy. Academy of Management Journal, 33(2), 233-258.

Gaebler Ventures. (n.d.). Cross-Training Employees. https://www.gaebler.com/Cross-Training-Employees.htm

Gallup. (2017). State of the American Workplace. Washington, DC: Gallup.

Gilsdorf, K., \& Hanleybrown, F. (2017). Investing in Entry-Level Talent: Retention Strategies that Work. Kimberly and FSG.

Good Jobs Institute. (n.d.). Standardize \& Empower. https://goodjobsinstitute.org/standardize-empower/

Grewal, D., Roggeveen, A. L., Sisodia, R., \& Nordfält, J. (2017). Enhancing customer engagement through consciousness. Journal of Retailing, 93(1), 55-64. doi:10.1016/j.jretai.2016.12.001

Hartline, M. D., \& Ferrell, O. C. (1996). The management of customer-contact service employees: An empirical investigation. Journal of Marketing, 60(4), 52-70. doi:10.2307/1251901

Hausknecht, J. P., \& Trevor, C. O. (2011). Collective turnover at the group, unit and organizational levels: Evidence, issues, and implications. Journal of Management, 37(1), 352-388. doi:10.1177/0149206310383910

Hausknecht, J. P., Trevor, C. O., \& Howard, M. J. (2009). Unit-level voluntary turnover rates andcustomer service quality: Implications of group cohesiveness, newcomer concentration, and size. The Journal of Applied Psychology, 94(4), 1068-1075. doi:10.1037/a0015898 PMID:19594245

Heineke, J., \& Davis, M. M. (2007). The emergence of service operations management as an academic discipline. Journal of Operations Management, 25(2), 364-374. doi:10.1016/j.jom.2006.11.003

Henly, J. R., \& Lambert, S. J. (2014). Unpredictable work timing in retail jobs: Implications for employee worklife conflict. Industrial \& Labor Relations Review, 67(3), 986-1016. doi:10.1177/0019793914537458

Hinkin, T. R., \& Tracey, J. B. (2010). What makes it so great? An analysis of human resourcespractices among Fortune's best companies to work for. Cornell Hospitality Quarterly, 51(2), 158-170. doi:10.1177/1938965510362487

Hochschild, A. R. (1983). The Managed Heart: Commercialization of Human Feeling. University of California Press.

Holtom, B., \& Burch, T. (2016). A model of turnover-based disruption in customer services. Human Resource Management Review, 26(1), 25-36. doi:10.1016/j.hrmr.2015.09.004 
Hunt, S. D. (1997). Competing through relationships: Grounding relationship marketing in resourceadvantage theory. Journal of Marketing Management, 13(5), 431-445. doi:10.1080/0267257X.1997.9964484

Kacmar, K. M., Andrews, M. C., Rooy, D. L. V., Steilberg, R. C., \& Cerrone, S. (2006). Sure everyone canbe replaced...but at what cost? turnover as a predictor of unit-level performance. Academy of Management Journal, 49(1), 133-144. doi:10.5465/amj.2006.20785670

Kallenberg, A. L. (2011). Good jobs, bad jobs: The rise of polarized and precarious employment systems in the United States, 1970s to 2000s. Russell Sage Foundation.

Kasemsap, K. (2014). The role of knowledge management on job satisfaction: A systematic framework. In Advances in Secure Computing, Internet Services, and Applications (pp. 104-127). IGI Global. doi:10.4018/978$1-4666-4940-8 . \operatorname{ch} 006$

Kasemsap, K. (2017). Examining the roles of job satisfaction and organizational commitment in the global workplace. In Handbook of Research on Human Resources Strategies for the New Millennial Workforce. IGI Global.

Lambert, S. J. (2008). Passing the buck: Labor flexibility practices that transfer risk onto hourly workers. Human Relations, 61(9), 1203-1227. doi:10.1177/0018726708094910

Lambert, S. J., \& Henly, J. R. (2009). Scheduling in hourly jobs: promising practices for the twenty-first century economy. The Mobility Agenda.

Lepak, D. P., Liao, H., Chung, Y., \& Harden, E. E. (2006). A conceptual review of human resource management systems in strategic human resource management research. In J. J. Martoccio (Ed.), Research in Personnel and Human Resources Management (pp. 217-271). Emerald Group Publishing Limited. doi:10.1016/S07427301(06)25006-0

Loungani, P., \& Mishra, S. (2014). Not your father's service sector. Finance \& Development, 51(2), 51-54.

Luria, G., Yagil, D., \& Gal, I. (2014). Quality and productivity: Role conflict in the service context. Service Industries Journal, 34(12), 955-973. doi:10.1080/02642069.2014.915948

Madhani, P. M. (2020a). (forthcoming). Lean six sigma deployment in retail industry: Enhancing competitive advantages. The IUP Journal of Business Strategy, 17(3).

Madhani, P. M. (2020b). Performance optimisation of retail industry: Lean six sigma approach. ASBM Journal of Management, 13(1), 74-91.

Martin, R. L. (2017). It's time to make more jobs good jobs. Harvard Business Review, 4(December). https:// hbr.org/2017/12/its-time-to-make-more-jobs-good-jobs

Maslach, C., \& Leiter, M. P. (2008). Early predictors of job burnout and engagement. The Journal of Applied Psychology, 93(3), 498-512. doi:10.1037/0021-9010.93.3.498 PMID:18457483

Meuris, J., \& Leana, C. R. (2015). The high cost of low wages: Economic scarcity effects in organizations. Research in Organizational Behavior, 35, 143-158. doi:10.1016/j.riob.2015.07.001

Milkovich, G. T., \& Newman, J. M. (2002). Compensation. McGraw-Hill.

Pfeffer, J. (1995). Competitive Advantage Through People. Harvard Business Press.

Prokesch, S. (2017). The right thing to do. Harvard Business Review. https://hbr.org/2017/12/the-right-thing-to-do

Rafaeli, A., Altman, D., Gremler, D., Huang, M., Grewal, D., Iyer, B., Parasuraman, A., \& de Ruyter, K. (2017). The future of frontline research. Journal of Service Research, 20(1), 91-99. doi:10.1177/1094670516679275

Rapp, A., Baker, T. L., Bachrach, D. G., Ogilvie, J., \& Beitelspacher, L. S. (2015). Perceived customer showrooming behavior and the effect on retail salesperson self-efficacy and performance. Journal of Retailing, 91(2), 358-369. doi:10.1016/j.jretai.2014.12.007

Reynolds, K. L., \& Harris, L. C. (2006). Deviant customer behavior: An exploration of frontlineemployee tactics. Journal of Marketing Theory and Practice, 14(2), 95-111. doi:10.2753/MTP1069-6679140201 
Roberts, P. W., \& Dowling, G. R. (2002). Corporate reputation and sustained superior financialperformance. Strategic Management Journal, 23(12), 1077-1093. doi:10.1002/smj.274

Rosenthal, P. (2004). Management control as an employee resource: The case of front-line service workers. Journal of Management Studies, 41(4), 601-622. doi:10.1111/j.1467-6486.2004.00446.x

Ryan, A. M., Schmit, M. J., \& Johnson, R. (1996). Attitudes and effectiveness: Examining relations at anorganizational level. Personnel Psychology, 49(4), 853-882. doi:10.1111/j.1744-6570.1996.tb02452.x

Schaufeli, W. B., \& Bakker, A. B. (2004). Job demands, job resources, and their relationship withburnout and engagement: A multi-sample study. Journal of Organizational Behavior, 25(3), 293-315. doi:10.1002/job.248

Schwartz, T. (2011). What it takes to be a great employer. Harvard Business Review. Available at: https://hbr. org/2011/01/what-it-takes-to-be-a-great-em.html/

Scott, M. M., \& Spievack, N. (2019). Making the Business Case for Employee Well-Being: Building Evidence to Scale Innovative Well-Being Benefits at Work. Urban Institute.

Shapiro, C. (1983). Premiums for high quality products as returns to reputations. The Quarterly Journal of Economics, 98(4), 659-679. doi:10.2307/1881782

Singh, J. (2000). Performance productivity and quality of frontline employees in service organizations. Journal of Marketing, 64(2), 15-34. doi:10.1509/jmkg.64.2.15.17998

Singh, J., Brady, M., Arnold, T., \& Brown, T. (2017). The emergent field of organizational frontlines. Journal of Service Research, 20(1), 3-11. doi:10.1177/1094670516681513

Staw, B. M. (1980). The consequences of turnover. Journal of Occupational Behaviour, 1(4), $253-273$.

Su, Z. X., Wright, P. M., \& Ulrich, M. D. (2018). Going beyond the SHRM paradigm: Examining four approaches to governing employees. Journal of Management, 44(4), 1598-1619. doi:10.1177/0149206315618011

Subramony, M. (2009). A meta-analytic investigation of the relationship between HRM bundles and firm performance. Human Resource Management, 48(5), 745-768. doi:10.1002/hrm.20315

Subramony, M., Ehrhart, K., Groth, M., Holtom, B. C., van Jaarsveld, D. D., Yagil, D., Darabi, T., Walker, D., Bowen, D. E., Fisk, R. P., Grönroos, C., \& Wirtz, J. (2017). Accelerating employee-related scholarship in service management. Journal of Service Management, 28(5), 837-865. doi:10.1108/JOSM-02-2017-0055

Subramony, M., \& Holtom, B. C. (2012). The long-term influence of service employee attrition on customer outcomes and profits. Journal of Service Research, 15(4), 460-473. doi:10.1177/1094670512452792

Subramony, M., \& Pugh, S. D. (2015). Services management research: Review, integration, and future directions. Journal of Management, 41(1), 349-373. doi:10.1177/0149206314557158

Sun, L. Y., Aryee, S., \& Law, K. S. (2007). High-performance human resource practices, citizenship behavior, and organizational performance: A relational perspective. Academy of Management Journal, 50(3), 558-577. doi:10.5465/amj.2007.25525821

Susskind, A. M., Kacmar, K. M., \& Borchgrevink, C. P. (2003). 'Customer service providers' attitudes relating to customer service and customer satisfaction in the customer-server exchange'. The Journal of Applied Psychology, 88(1), 179-187. doi:10.1037/0021-9010.88.1.179 PMID:12675405

Ton, Z. (2012). Why good jobs are good for retailers. Harvard Business Review, 9(1/2), 124-131. PMID:22299511

Ton, Z. (2014). The Good Jobs Strategy: How the Smartest Companies Invest in Employees to Lower Costs and Boost Profits. Houghton Mifflin Harcourt.

Ton, Z. (2015). A new way to rate retailers on providing good jobs. Harvard Business School Cases. https://hbr. org/2015/09/a-new-way-to-rate-retailers-on-providing-good-jobs

Ton, Z. (2017a). The god jobs solution. Harvard Business Review, (December), 20.

Ton, Z. (2017b). The case for good jobs. Harvard Business Review. https://hbr.org/cover-story/2017/11/thecase-for-good-jobs 
Ton, Z. (2017c). How to build a business on good jobs. Harvard Business Review, l(December). https://hbr.org/ cover-story/2017/11/the-case-for-good-jobs

Ton, Z. (2020). The Pioneering good jobs strategy is heading mainstream. https://mitsloan.mit.edu/fellows/ leadership-blog/the-pioneering-good-jobs-strategy-is-heading-mainstream/

Ton, Z., \& Harrow, S. (2010). Mercadona. Harvard Business School Case (610-089).

Ton, Z., \& Kalloch, S. (2017). Transforming today's bad jobs into tomorrow's good jobs. Harvard Business Review, 12(June). https://hbr.org/2017/06/transforming-todays-bad-jobs-into-tomorrows-good-jobs

Turban, D. B., \& Cable, D. M. (2003). Firm reputation and applicant pool characteristics. Journal of Organizational Behavior, 24(6), 733-751. doi:10.1002/job.215

Van Iddekinge, C. H., Ferris, G. R., Perrewe, P. L., Perryman, A. A., Blass, F. R., \& Heetderks, T. D. (2009). Effects ofselection and training on unit-level performance overtime: A latent growth modelling approach. The Journal of Applied Psychology, 94(4), 829-843. doi:10.1037/a0014453 PMID:19594228

Verhoef, P. C., Lemon, K. N., Parasuraman, A., Roggeveen, A., Tsiros, M., \& Schlesinger, L. A. (2009). Customer experience creation: Determinants, dynamics and management strategies. Journal of Retailing, 85(1), 31-41. doi:10.1016/j.jretai.2008.11.001

Williams, J. C., \& Huang, P. (2011). Improving work-life fit in hourly jobs: an underutilized cost-cutting strategy in a globalized world. Center for WorkLife Law. San Francisco: University of California Hastings College of Law.

Zablah, A., Sirianni, N., Beatty, S., Korschun, D., \& Gremler, D. (2017). Emotional convergence in service relationships. Journal of Service Research, 20(1), 76-90. doi:10.1177/1094670516675405 